\title{
Using Educational Technology to Enhance Teaching and Learning EFL (A Case Study of English Language Teachers- KKU- Faculty of Sciences and Arts at Muhayle Assir)
}

\author{
Abdul-Gayoum M. A. Al-Haj \\ College of Graduate Studies, University of the Holy Qurãn, Wadmadani, Sudan
}

\begin{abstract}
This paper aims at investigating the method of applying educational technology to enhance TEFL in the Faculty of Sciences and Arts at Muhayle Aassir. The researcher uses close-ended questions interview and direct observation as instruments for collecting the data, and then he uses the descriptive method to analyse them. He chooses these two instruments as most appropriate for exchanging and evaluating ideas about using educational technology to enhance teaching EFL in the prescribed faculty. He, also, uses the observational method to study classroom events. The interview was held with 20 teachers of the English Department in order to get valuable information for the study. Furthermore, the researcher uses the SPSS programme to compute the data. The following are the study findings: Firstly; the usage of mere traditional devices in instruction has a poor efficiency on LEFL at the above-mentioned faculty. Secondly; there is effectiveness in using educational technology in teaching. Thirdly; it seems that the Faculty of Sciences and Arts provides training for the English language teachers with regard to educational technology, but in vain. The researcher recommends that English language teachers, of Faculty of Sciences and Arts, should facilitate and enhance learning via using educational technology- in their teaching- in order to keep students more interested and more engaged with the topic which is presented.
\end{abstract}

Index Terms - educational technology, integration, enhances learning, English as a Foreign Language (EFL), close-ended questions interview

\section{INTRODUCTION}

The researcher believes that the proficiency in foreign languages, at least two of them, opens wide doors for work and knowledge, and gives the person who masters some foreign languages great acceptance among different peoples almost in all countries around the world. Being that the case, the researcher calls for the development of foreign languages education in Saudi Arabia, in particular the English language which is treated as a foreign language since it is not used as a medium of instruction in schools or universities and not used as a means of communication in the daily life speech. Alrabai, F. (2016) asserted that, "despite the enormous efforts of the Saudi government to improve English teaching and learning in the country, students' English proficiency remains unsatisfactory and far below expectations... According to the statistics released in the third edition of The Official Guide to the TOEFL Test (2009), the average TOEFL result in Saudi Arabia is 57 out of 120, which is the second lowest in the entire Middle East and among the lowest average TOEFL scores in the world. The low competence in EFL among Saudi learners can be attributed to a variety of multidimensional factors." (p. 21).

Teachers cannot depend completely on their students' interests and needs of learning a FL, yet they should motivate learning whenever they find a chance to do that. Seeking for motivating their students, most teachers use various devices of technology and online computer programmes in teaching. But it is not an easy process, as evidenced by Laura Turner, (2005, p.1) who stated that "whether you are involved in higher education, secondary education, elementary education, or special education all of us find it difficult to cope with fast-developing of computer- based technology. " However, in the field of teaching and learning EFL there is a universal trend that in order to make learning an effective process you have to use technology in your teaching. Ibrahim M. A. \& Khalid A. (2014) contended that "the introduction of new technology into schools has determined changes in pedagogy where teachers are adopting new methods of teaching facilitated by the new technology. Technology offers powerful learning and teaching tools that demand new skills and understandings both from learners and teachers. This may provide better results of teaching effectiveness compared to traditional teaching methods." (p.105).

Ontario Ministry of Education (2000) presents the role of technology in the curriculum as follows: "Increasing reliance on computers, telecommunication networks, and information technologies in society and the workplace makes it essential for students to become computer literate and to develop 'information literacy' skills. Information literacy is the ability to access, select, gather, critically evaluate, create, and communicate information, and to use the information obtained to solve problems and make decisions. In preparation for further education, employment, citizenship, and 
lifelong learning, students must be capable of deriving meaning from information by using a wide variety of information literacy skills." (p.9).

Moreover, the term 'Technology Enhanced Learning' (TEL) is increasingly being used worldwide. To bear the above mentioned piece of information in mind, it is no longer agreed to or approved by any teacher to be technology illiterate. Interested in educational technology after he has utilised it in teaching EFL- in some universities in the Sudan and the Kingdom of Saudi Arabia- for almost seven years, the researcher felt certain of the benefits of it. Hence, the idea that this area of knowledge is expected to be exciting- especially in the Kingdom- has encouraged the researcher to make a research on it.

\section{A. Statement of the Problem}

This part of the study submits the cause of the research paper and generates the questions which the research aims to answer. For asserting this fact, the researcher states that the questions to be examined in this paper are interrelated and therefore, can be summarized and assembled in one question as follows: 'How utilisation of educational technologies enhances teaching and learning EFL?'

Alrabai, F. (2016) emphasized that "low achievement in the foreign language learning is the result of a complex interaction of both internal and external factors. For example, a controlling, aggressive teacher is an external factor that negatively affects learners' motivations, while the anxiety that such teachers instil in their students is an internal factor that negatively affects students' learning outcomes." (p. 22). He took the same issue further when he said that "learners come to school with motivation and enthusiasm, but when they begin to encounter certain external practices, such as responding to their teachers' questions, completing their assignments, taking tests, and having their performances monitored, graded, and reported to their parents, learners may begin to find school anxiety-provoking and psychologically threatening." (Alrabai F., 2016, p. 22).

English Language Teachers of Faculty of Sciences and Arts at Muhayle Assir- cannot depend on traditional type of teaching and on their students' interests for learning a FL, yet should motivate learning by using modern methods rather than traditional ones. Therefore, this research paper is an attempt to give those teachers confidence to use educational technology in their teaching in order to improve the quality of students' participation in learning English as a Foreign Language.

\section{B. Questions of the Study}

1. Does traditional type of teaching enhance learning EFL in the Faculty of Sciences and Arts at Muhayle Aassir?

2. Does utilisation of educational technology in teaching EFL, in the Faculty of Sciences and Arts at Muhayle Aassir, encourage broader students' participation and collaboration?

3. Will learning become fun for students by utilising educational technology in teaching EFL in the Faculty of Sciences and Arts at Muhayle Aassir?

\section{Hypotheses of the Study}

1. Traditional type of teaching does not improve the quality of learning EFL, in the Faculty of Sciences and Arts at Muhayle Aassir, since it lacks effective interaction between English as Foreign Language teachers and their students.

2. There will not be broader students' participation and collaboration without utilising educational technology in teaching EFL in the Faculty of Sciences and Arts at Muhayle Aassir.

3. Learning EFL, in the Faculty of Sciences and Arts at Muhayle Aassir, will become fun for students by utilising educational technology in teaching.

\section{Significance of the Study}

The significance of this research paper is determined by how we benefit from it and how the specific audience will be helped by its findings. Considering this piece of information, the researcher expects some advantages of this study because it will be of importance to community as it is about a universal area of interest. Moreover, it may help in providing teachers with academic information about their career. Then, the researcher is longing for this paper to be an attempt by which he can help the interested readers in the field- teachers who are concerned with English as a Foreign Language, and those who work in the field of LT and applied linguistics- to carry on further researches in this area of knowledge.

\section{E. Limitations and Delimitations}

In this research paper the concentration will be on utilising educational technology in teaching EFL in the Faculty of Sciences and Arts at Muhayle Aassir - in the second semester of the academic year 2018-2019. In other words, this paper will examine the quality of making use of educational technology in TEFL at the above setting.

Technology is quite expensive to implement. Some areas have no power and internet, so it becomes very difficult to use educational technology. Teachers will have to be trained on how technology works. We are used to teachers who are teaching students, in spite of the fact that not themselves getting taught. Some students will find it difficult to deal with these technologies without a guide from their teachers. 


\section{LITERATURE REVIEW}

Keep in his mind that the standards of English language four main skills have declined a lot especially speaking which is considered as the most important skill of the four ones, the researcher thinks very carefully about sharing in solving such a problem. In connection with the development of foreign languages education, the researcher offers a possible opinion of utilising educational technology to enhance Teaching English as a Foreign Language in the Faculty of Sciences and Arts at Muhayle Aassir.

\section{A. What is Educational Technology?}

Adam Bellow (2016) said, "I think to define technology integration; it's really using whatever resources you have to the best of your ability. Technology is a tool. It's what you do with that tool, what you can make, what you allow the students to make. That's really what technology is all about." (From the blog-Edutopia). In accordance with his own experience and continuous observations the researcher thinks that educational technology is an area of study that uses the processes of analyzing, designing, developing, implementing and evaluating the learning materials with their all types in order to improve and elevate teaching and learning or to achieve instructional objectives. The usage of physical hardware, software, and educational theories comprises educational technology which is- at the present time- used to facilitate learning and improving teachers and students' performance by creating, using and managing suitable technological processes and resources. This is done in particular for increasing performance within the educational system. According to U.S. Department of Education, (2017) "Technology can empower educators to become colearners with their students by building new experiences for deeper exploration of content. This enhanced learning experience embodies John Dewey's notion of creating 'more mature learners.' Side-by-side, students and teachers can become engineers of collaboration, designers of learning experiences, leaders, guides, and catalysts of change.” (p.28)

\section{B. Educational Technology versus Traditional Type of Teaching}

The researcher wonders how his own classroom was looked like round about thirty-five years ago. He claims that his teachers; instead of using computers they used books, instead of having videos they used cassette tapes and recorders, and instead of having interactive white boards they used chalkboards / blackboards. "Education is evolving due to the impact of the Internet. We cannot teach our students in the same manner in which we were taught. Change is necessary to engage students not in the curriculum we are responsible for teaching, but in school. Period." (Chamberlain, 2016). John Dewey (2011) once said, "If we teach today as we taught yesterday, we rob our children of tomorrow." (Press release). As it is presented in the introduction, teachers should not depend completely on the involvements and needs of their students for learning English as a Foreign Language, yet they should stimulate learning whenever they find a chance to do that. Fortunately, through his continuous observations, the researcher notices that students have enchanted with technology devices and that they know how to operate them efficiently, especially their smart phones. According to David W. (2016) "We need technology in every classroom and in every student and teacher's hand, because it is the pen and paper of our time, and it is the lens through which we experience much of our world." (Search Quotes). Hence, the researcher is interested in the things teachers should do in order to make learning exciting with mixing technology with traditional means.

Aziz, H. (2010) stated that "educational technology is the implementation of appropriate tools, techniques, or processes that facilitate the application of senses, memory, and cognition to enhance teaching practices and improve learning outcomes." (p.1). As far as senses are concerned, Amy B. (2018) provides an ancient Chinese proverb; "I hear and I forget. I see and I remember. I do and I understand." (Search twitter). Accordingly, the five senses are of great value in the process of learning. Hence, EFL teachers can make use of them to stimulate their students while they are learning. These teachers should know that the more you use senses while you are using educational devices in teaching your students the more those students understand you.

All of us- as EFL teachers- find it very difficult to catch up, keep up, and put up with fast-developing computer-based technology. Therefore, it is no longer acceptable for us to be technology illiterate, while the others are longing for keeping pace with technology accelerating development. Cindy G.\& Karuri M. (2015) wrote "Everyone agrees that technology can be used in the classroom to the benefit of the students, and there is no stopping the advancement of technology. The challenge is in how the technology is implemented, utilized, and monitored." (p.1141).

\section{How to Make TEFL Lively and Fun?}

Hutchinson and Waters (1987) claimed that "EFL, as much as any good teaching, needs to be intrinsically motivating. It may, still, need to be sweetened with the sugar of enjoyment, fun, creativity, and a sense of achievement." (Cited in Al-Haj, A. M., 2011, p.526). It is thought by most EFL teachers that, educational technologies are tools that, when used correctly, helps teachers to make their teaching more versatile, modern, and engaging for students. Adam Bellow (2016) said, "If you can do a lesson without technology, that's great but knowing that you can do it better with technology, that's why you use tools." (From the blog-Edutopia). With regard to applying educational technology into teaching EFL, the most important goal is to enable teachers and students to gather, access, analyse, present and transmit information in a new and different manner. In this particular way, teachers of EFL can make information available in classrooms as well as can make the teaching of students with special needs interesting and attractive or special in some way.

Surely, technology is one of the means and incentives by which teachers can arouse their students' interest while they 
are teaching. Today, technology has the ability to enhance relationships between teachers and students since there are portable and easy to use devices like; Smartphone, personal digital assistants, eBook readers and laptops, etc. "When technology is effectively integrated into subject areas, teachers grow into roles of advisers, content experts, and coaches. Technology helps make teaching and learning more meaningful and fun". (Kenneth T. Henson, 2015, p.22). Al-Haj, A. M. (2011) asserted that "activities carried out in groups may help to motivate and encourage the more diffident students and those who are evasive, or afraid to ask or speak for fear of making errors, that is because activities carried out in groups will transfer the process of learning from getting the skill of the language to using it." (p. 526).

From a set of papers in the issue of CITE, Mouza, C. (2018) provides the following piece of information about integrating technology; "new approaches to integrating technology in teacher education that move beyond stand-alone courses to explicitly address content and pedagogy in methods courses and field experiences. These papers address teacher education and professional development practices that not only familiarize teachers with new technologies but help them acquire firsthand experiences of what it means to learn with technology." (p. 491).

\section{MATERIALS AND METHODS}

The researcher used the descriptive method to describe, organize and summarize the data by making use of two instruments: direct observation and close-ended questions interview held with 20 teachers of the English Department in order to give their views on the points below which were contained in the interview as guides (i.e. domains):

- professional development,

- traditional classroom activities,

- resources to integrate technology,

- teachers' workload, and

- teachers' attitudes towards integration of technology.

The interview schedule contained 20 questions each five of them were set under one of the above guides (domains). The researcher, also, used an observational method to study classroom events. He chose these two tools as most appropriate for exchanging and evaluating ideas about using educational technology to enhance teaching EFL in the prescribed setting. Furthermore, the researcher used the SPSS programme in order to compute the data. Then, for the collection of relevant data, the interview was held and observations of teachers' class room behavior were conducted.

\section{RESULTS AND DiSCUSSION}

The technique of presenting the results is that the researcher organized them around the hypotheses of the study. Then, he discovers that the easiest way is to report the study results and frame them around the research questions or hypotheses which he has formulated already. To do this job, he uses only the results of the following eight questions out of the 20 questions of the interview schedule.

\section{A. The First Hypothesis}

The result of table (1) presents that English language teachers of the Faculty of Sciences and Arts at Muhayle Assir do not prefer traditional type of teaching. To take full advantage of this result, the researcher asked them about the reason, and then almost all of them said that their students would collaborate and engage in learning EFL whenever they used modern technology devices in their teaching. Analyzing qualitative data is difficult, however, the researcher did his best to attend three lectures, and then collected detailed qualitative data - from inside the lecture rooms - about whether English language teachers utilize traditional type of teaching or not and whether they integrate educational technology in teaching EFL or not. Ultimately, the researcher noticed that some of the English language teachers did not use pure traditional type of teaching, yet on the contrary they used blended type of instruction.

Considering these results, the researcher states that they agree with the first hypothesis (that) "Traditional type of teaching does not improve the quality of learning EFL, in the Faculty of Sciences and Arts at Muhayle Aassir, since it lacks effective interaction between English as Foreign Language teachers and their students."

TABLE 1.

Q1. Do YOU PREFER TRADITIONAL TYPE OF TEACHING?

\begin{tabular}{|cc|c|c|c|c|}
\hline \multicolumn{6}{|c|}{ Q1. DO YOU PREFER TRADITIONAL TYPE OF TEACHING? } \\
\hline \multirow{2}{*}{ Valid } & Frequency & Percent & Valid Percent & Cumulative Percent \\
& yes & 8 & 40.0 & 40.0 & 40.0 \\
& no & 12 & 60.0 & 60.0 & 100.0 \\
& Total & 20 & 100.0 & 100.0 & \\
\hline
\end{tabular}

This result of table (2) does not oppose the above result of table (1) which shows that English language teachers stand for the viewpoint of integrating traditional devices with modern technology ones in order to utilise blended teaching. But, what is surprising is that most of those teachers did not use educational technology in their teaching in spite of the fact that they were convinced of its effectiveness. 
TABLE 2.

Q2. HAVE YOU COMBINED TRADITIONAL DEVICES WITH MODERN TECHNOLOGY ONES IN YOUR TEACHING?

\begin{tabular}{|cc|c|c|c|c|}
\hline & Frequency & Percent & Valid Percent & Cumulative Percent \\
\hline \multirow{4}{*}{ Valid } & yes & 19 & 95.0 & 95.0 & 95.0 \\
& no & 1 & 5.0 & 5.0 & 100.0 \\
& Total & 20 & 100.0 & 100.0 & \\
\hline
\end{tabular}

\section{B. The Second Hypothesis}

These three tables from (3) - (5), which are exactly $100 \%$, show that English language lecturers of Faculty of Sciences and Arts at Muhayle Assir, officially, agree to the idea of using educational technology in their teaching. The observational results- which are discussed above in detail- agreed with the results of the interviews, and at the very same time they are supported by them. This is being the case; the researcher claims that all these results reflect the second hypothesis that "There will not be broader students' participation and collaboration without utilising educational technology in teaching EFL in the Faculty of Sciences and Arts at Muhayle Aassir." Unfortunately, most of the English language teachers in this faculty did not use educational technology in their teaching, although they are certain of its effectiveness.

TABLE 3.

Q3. Do YOU THINK IT IS APPROPRIATE FOR YOUR STUDENTS TO BE USING THE INTERNET?

\begin{tabular}{|l|l|l|l|l|}
\hline & Frequency & Percent & Valid Percent & Cumulative Percent \\
\hline Valid yes & 20 & 100.0 & 100.0 & 100.0 \\
\hline
\end{tabular}

TABLE 4.

Q4. WILL IT BE SUITABLE FOR YOUR STUDENTS TO BE USING TECHNOLOGY DEVICES IN LEARNING ENGLISH?

\begin{tabular}{|c|c|c|c|c|}
\hline & Frequency & Percent & Valid Percent & Cumulative Percent \\
\hline Valid yes & 20 & 100.0 & 100.0 & 100.0 \\
\hline
\end{tabular}

TABLE 5 .

Q5. DOES UTILISATION OF EDUCATIONAL TECHNOLOGY IN TEACHING EFL ENCOURAGE STUDENTS' PARTICIPATION AND COLLABORATION?

\begin{tabular}{|cc|c|c|c|c|}
\hline & Frequency & Percent & Valid Percent & Cumulative Percent \\
\hline \multirow{2}{*}{ Valid } & yes & 19 & 95.0 & 95.0 & 95.0 \\
& no & 1 & 5.0 & 5.0 & 100.0 \\
& Total & 20 & 100.0 & 100.0 & \\
\hline
\end{tabular}

\section{The Third Hypothesis}

Results of tables (6) - (8), which are 90\% and above indicate that the Faculty of Sciences and Arts at Muhayle Aassir provides training for the English language teachers with regard to utilizing educational technology in their teaching. Considering the preceding findings the researcher claims that the study has operated since there is an agreement between the results of the interviews and the observational comments. Thus, these results supported the third hypothesis of the study which read: "Learning EFL, in the Faculty of Sciences and Arts at Muhayle Aassir, will become fun for students by utilising educational technology in teaching". They are also corresponding to the former opinion of Kenneth T. Henson (2015) "When teachers effectively integrate technology into subject areas, teachers grow into roles of advisers, content experts, and coaches. Technology helps make teaching and learning more meaningful and fun." (p. 75)

TABLE 6.

Q6. DOES TECHNOLOGY FIT INTO THE TEACHER EdUCATION PROGRAMME?

\begin{tabular}{|lc|c|c|c|c|}
\hline & Frequency & Percent & Valid Percent & Cumulative Percent \\
\hline Valid yes & 20 & 100.0 & 100.0 & 100.0 \\
\hline
\end{tabular}

TABLE 7.

Q7. Do You MaKe Learning Fun For STUdents By Using EduCATIONAL TeChNOLOGy Devices?

\begin{tabular}{|cc|c|c|c|c|}
\hline & Frequency & Percent & Valid Percent & Cumulative Percent \\
\hline Valid & yes & 19 & 95.0 & 95.0 & 95.0 \\
& no & 1 & 5.0 & 5.0 & 100.0 \\
& Total & 20 & 100.0 & 100.0 & \\
\hline
\end{tabular}

TABLE 8.

Q8. Is There ANy Professional DeVelopment TRaining AVAilable For You From Your Faculty?

\begin{tabular}{|cc|c|c|c|c|}
\hline & & Frequency & Percent & Valid Percent & Cumulative Percent \\
\hline \multirow{2}{*}{ Valid } & yes & 18 & 90.0 & 90.0 & 90.0 \\
& no & 2 & 10.0 & 10.0 & 100.0 \\
& Total & 20 & 100.0 & 100.0 & \\
\hline
\end{tabular}




\section{CONCLUSION, RECOMMENDATIONS AND FutuRE RESEARCH}

As it shown above from the previous studies, technology has a vivid effect on university education. But, there is still much to be learned about its contribution in teaching English as a foreign language. The researcher hopes that the findings below will be considered by English Language teachers:

- Traditional type of teaching lacks proper communication between teachers and their students, as it is not an effective means by which students can master the main skills of learning EFL.

- Technology is motivating and stimulating for students:

- Students feel much more motivated.

- Students can use interactive multimedia exercises.

- Technology changes students from being passive to active learners.

- Technology is the best complementary tool for teachers in the classroom:

- Teachers can motivate their students.

- Classes can be much richer in content.

- It helps in implementing a blended learning method.

- Technology assists in managing and monitoring student progress:

- Provides the most effective control over activities.

- Create a unique experience as much for the teacher as the students.

- Promote interactivity and collaboration within learning.

- Technology provides teachers with attractive resources.

- Through educational technology teaching is more effective.

- Using educational technology in teaching EFL generates great need for knowledge, information and skills which encourage the present day generation to collaborate as one team in order to live a fruitful life.

- Utilisation of educational technology in teaching EFL encourages broader students' participation and collaboration.

- Learning EFL will become lively and fun for students by utilising educational technology in teaching.

To make the process of learning EFL in KKU University- Faculty of Sciences and Arts at Muhayle Assir a more motivating and effective experience, the researcher submits the following recommendations to the English Language teachers:

- Be knowledgeable and competent to operate educational devices.

- Be aware, appreciative and equipped on using these educational devices.

- Establish guidelines.

- Adopt variations of technology.

- Provide access to your students.

- Encourage student interaction.

- keep a backup plan.

- Avoid over use educational technology devices.

Moreover, because of their importance, what if we combined technology and past educational materials? I think the present day learners will enjoy it. In addition to that, it will develop teaching-learning interaction. Then, everything will be balanced when using traditional and modern learning environment.

The researcher longs that this study to be as a real contribution to debates in its field and to enrich subsequent research activities by teachers and academic developers. In other words, he claims that three advantages can be gained from this study. First, the study will be of importance as it is on an issue of the field of education. Second, may help in giving teachers academic information that concerning their career. Third, the researcher has good reasons to think that this paper will be a test to discover how effective or suitable to utilize educational technology in teaching EFL or an attempt by which the researcher can help the specialized audiences particularly in the countries in which English language is treated as a foreign language- audiences such as; interested readers, teachers who are concerned with EFL, and those who work in the field of LT and applied linguistics- to carry on further researches in this area of knowledge. Kirkwood and Price (2013) declared that, "Academics and managers need a clear articulation of what is meant by Technology Enhanced Learning (TEL) in higher education to develop a better understanding of achievements. This is vital if research is to inform future practices in teaching and learning with technology to maximum effect." (p.20).

\section{REFERENCES}

[1] Adam, B. (2016). Amazing Video on Technology Integration in the Classroom.. From the plog Video by Edutopia. February 9 , 2016. Edupedia Team. Available online at: http://edupedia-eg.com/edupedia/2016/02/09/amazing-video-on-technology.

[2] Al-Haj, A. M. (2011). Enhancing Motivation in the EFL Classrooms Is the Solution (A Case Study of Secondary Schools of the Gezira State, Sudan) Journal of Language Teaching and Research, Vol. 2, No. 3, pp. 524-529. Available online at: http://www.academypublication.com/issues/past/jltr/vol02/03/04.pdf.

[3] Alrabai, F. (2016). Factors Underlying Low Achievement of Saudi EFL Learners. International Journal of English Linguistics; Vol. 6, No. 3, PP. 21-37 Available online at: file:///C:/Users/DELL/Downloads/57994-212150-1-PB\%20(1).pdf.

[4] Amy B. (2018). What I hear. Ancient China Projects! \#CharlesPMurray\# Eclipsethinking Confucius. 3:29 PM May 3, 2018. Twitter for iPhone Available at: https://twitter.com/Amosbeech/status/992033329556918278. 
[5] April Chamberlain. (2016). Technology in Education. How technology is influencing education. Qutes. MAY 5, 2016 Available online at: https://educationinis.wordpress.com/2016/05/05/april-chamberlain/.

[6] Aziz H. (2010). The 5 keys to educational technology. The Journal-Transforming Education Through Technology. 09/16/10. Available at: https://thejournal.com/articles/2010/09/16/the-5-keys-to-educational-technology.aspx.

[7] Chrystalla Mouza. (2018). Editorial: The Role of Teachers in Teaching and Learning with Technology. Contemporary Issues in Technology and Teacher Education, CITE Journal, 18(3), 491-493. Available online at: https://citejournal.s3.amazonaws.com/wp-content/uploads/v18i3editorial1.pdf.

[8] Cindy Greenman, Karuri Mwangi (2015). Does Technology Make a Difference in Student Success in an Accounting Classroom?. American Journal of Educational Research.; 3(9), PP. 1138-1141. doi: 10.12691/education-3-9-11. Available online at: http://pubs.sciepub.com/education/3/9/11/index.html.

[9] David, W. (2016). Technology Empowering Education. How technology is influencing education. Qutes., MAY 5, 2016 Available online at: https://educationinis.wordpress.com/2016/05/05/45/.

[10] Ibrahim M. A. \& Khalid A. (2014). Towards a Digital World: Using Social Networks to Promote Learner's Language. American International Journal of Contemporary Research Vol. 4, No. 10, PP.105-114. Availableat: http://www.aijcrnet.com/journals/Vol_4_No_10_October_2014/13.pdf.

[11] John Dewey (2011). If we teach today as we taught... PRESS RELEASE JAN 13, 2011, (Newswire.com) January 13, 2011. Available at: https://www.newswire.com/if-we-teach-today-as-we-taught/84104.

[12] Kenneth T. Henson, (2015) Curriculum Planning: Integrating Multiculturalism, Constructivism, and Education Reform, Fifth Edition. Long Grove, Illinois. Waveland https://books.google.com/books?id=20gaBgAAQBAJ\&pg=PR6\&lpg=PR6\&dq=Kenneth+T.+Henson,+(2015).

[13] Kirkwood, A. and Price, L. (2013). Technology-enhanced learning and teaching in higher education: what is 'enhanced' and how do we know? A critical literature review. Learning, Media and Technology, Institute of Educational Technology, The Open University, Milton Keynes MK7 6AA, UK. Available at: file:///C:/Users/DELL/Downloads/TELWhatisEnhanced.pdf.

[14] Laura Turner. (2005). 20 Technology Skills Every Educator Should Have. 06/01/2005 issue of the Journal. Transforming Education through Technology. Available at: https://thejournal.com/articles/2005/06/01/20-technology-skills-every-educatorshould-have.aspx.

[15] Mouza, C. (2017). Editorial: Beyond Stand-alone Educational Technology Coursework: K-16 Teacher Preparation Strategies. Contemporary Issues in Technology and Teacher Education, 17(3), PP. 291-294. Available at: file:///C:/Users/DELL/Downloads/article_181392.pdf.

[16] Ontario Ministry of Education. (2000). Program Planning and Assessment - The Ontario Curriculum, Grades 9 to 12: The Role of Technology in the Curriculum. Toronto: Queen's Printer for Ontario. Retrieved November 10, 2003 Available at: https://www.tcdsb.org/FORSTAFF/NewTeacherInduction/Documents/curric912planning.pdf.

[17] U S Department of Education. (2017). Office of Educational Technology, Reimagining the Role of Technology in Education: National Education Technology Plan Update, Washington, D.C., 2017. Available at: https://tech.ed.gov/files/2017/01/NETP17.pdf.

Abdul-Gayoum M. A. Al-Haj - Associate Professor - was born in Wadmadani central Sudan in 1955.

He has been awarded:

- $\quad$ Ph.D. in English Language (Applied Linguistics) from Nile Valley University- Omdurman- Sudan (2006).

- $\quad$ M.A. in Applied Linguistics, Gezira University- Wadmadani- Sudan (2003).

- $\quad$ B.A. in Education (English), Faculty of Education- University of Khartoum- Khartoum- Sudan (1985). Major field is Applied Linguistics \& ELT.

His research interests are to write research papers in Applied Linguistics and ELT. Previous publications:

- $\quad$ His research paper in the (JLTR), Volume 2, Number 3, May 2011

- Three Course Books:

- Nonfiction English - (Readings)

- Phonetics Made Easy

- Techniques of English Language Teaching

He has been awarded the HQU Prize for his research paper-about developing Juba Branch- which was classified as the best study out of (66) research papers. 